\title{
Assessing access to local food system initiatives in Fairbanks, Alaska
}

\author{
Alison M. Meadow, ${ }^{1}$ University of Alaska Fairbanks
}

Submitted 9 April 2011 / Revised 11 August 2011 / Accepted 31 August 2011 / Published online 29 February 2012

Citation: Meadow, A. M. (2012). Assessing access to local food system initiatives in Fairbanks, Alaska. Journal of Agriculture, Food Systems, and Community Development, 2(2), 217-236. http://dx.doi.org/10.5304/jafscd.2012.022.006

Copyright (C) 2012 by New Leaf Associates, Inc.

\begin{abstract}
Local food system initiatives are an increasingly popular attempt to address environmental and social-equity problems that seem to be inherent in the conventional global food system. However, relatively few studies have been undertaken to assess the ability of local food system initiatives to ameliorate these concerns. This study focuses on a community with food system vulnerabilities related to geographic isolation and a marginal agricultural climate that limits local food production. The study
\end{abstract}

1 Alison M. Meadow, Department of Anthropology/Resilience and Adaptation Program, University of Alaska Fairbanks.

Alison Meadow is now in the Department of Soil, Water and Environmental Science at the University of Arizona, 715 North Park Avenue, 2nd Floor, P.O. Box 210156, Tucson, Arizona 85719 USA; meadow@email.arizona.edu

This research was funded by the National Science Foundation's Arctic Social Sciences Program, University of Alaska Fairbanks' Integrative Graduate Education and Research Traineeship (IGERT) Program, and University of Alaska's Experimental Program to Stimulate Competitive Research (EPSCoR) Program. seeks to develop tools to test hypotheses important to this community and others: whether local foods can be as physically and economically accessible as conventional foods. Using spatial analysis and quantitative price comparisons, the study concludes that at this time, locally grown foods in Fairbanks, Alaska, are not as accessible as conventional foods. The tools applied in this study could be used elsewhere to develop a more robust literature on the impact of local food system initiatives on urban food systems.

\section{Keywords}

Alaska, food systems planning, geographic information systems (GIS), local food access

\section{Introduction}

The availability of food in a particular region or community does not guarantee food security for the people of that community (Sen, 1981). If access to food is not equitable, some sector of the population is likely to experience food insecurity. Access to food requires that food be physically accessible, affordable, and culturally or personally acceptable 
(Ericksen, 2008). As interest grows in increasing the amount of food grown within communities to feed community residents, in other words creating local food systems, it is important to assess whether local food system initiatives such as smallscale farms, farmers' markets, and communitysupported agriculture enterprises can provide the equitable access required to create a functional food system. Localization presents opportunities to address serious weaknesses in the conventional global food system (GFS), which relies on industrial food production techniques and functions at a global spatial scale. But, without rigorous assessments of nascent local food system (LFS) initiatives, we run the risk of replicating inequities or introducing new vulnerabilities in alternative food systems. Tools developed to assess food access and health issues, particularly among vulnerable populations, can be adapted to help LFS planners and practitioners better understand the current and potential role locally grown foods could play in food systems that achieve food access, nutritional security, and food security.

Using both spatial analysis and quantitative price comparisons, this study compares access (both physical and economic) to local and nonlocal vegetables in the current food system of Fairbanks, Alaska. This study hypothesized that locally grown foods are not as physically or economically accessible to lower-income residents as they are to higherincome residents. The study found that physical access to locally grown foods is lower for all Fairbanks residents, regardless of household income, but that higher prices for locally grown foods are likely to reduce economic access for lower-income households. By assessing the state of nascent LFS initiatives in one community, this study tests the use of food access assessment tools as applied to locally grown foods, identifies several challenges to making local food access equitable across all socioeconomic groups, and highlights areas where future research might uncover solutions to these challenges.

\section{Food System Scales and Choices}

While the popularity and viability of LFS initiatives have increased in recent years, their specific role in building comprehensive, functional food systems has yet to be fully examined. The goals of food system localization are often summarized as reducing food miles and associated energy use and pollution (Pirog \& Benjamin, 2003); providing food that has not been subject to long-distance shipping (Kloppenburg Jr., Hendrickson, \& Stevenson, 1996); building community relationships (Feenstra, 2002); increasing use of sustainable agricultural methods (Feenstra, 2002; Kloppenburg Jr., et al., 1996); supporting local economies (Feenstra, 2002); and improving food access by creating direct links between consumers and food production sites (Feenstra, 2002).

LFSs are not inherently sustainable, environmentally sound, or socially equitable — although they may make contributions to one or more of these objectives. LFSs have weaknesses, as does the more conventional GFS (Hendrickson \& Heffernan, 2002), including susceptibility to local disease, climate, and disturbance patterns (Sundkvist, Milestad, \& Jansson, 2005); overstressing of local resources (Sundkvist et al., 2005); and lack of social equity (Allen, 1999; Guthman, Morris, \& Allen, 2006; Hinrichs, 2003).

LFS initiatives have now been in place in enough communities for sufficient time to begin the process of evaluating their impacts, identifying their strengths and weaknesses, and developing a set of best practices that emerge from the process of assessment. To date there are relatively few studies that assess LFS initiatives' contribution to food security in developed countries and cities. Most research has focused on a lack of social equity in participation in LFS initiatives (see: Allen, 1999; Guthman, 2008; Hinrichs, 2003; Hinrichs \& Kremer, 2002; Macias, 2008). A smaller set of studies has examined the contribution of LFS initiatives, particularly gardening, to nutritional outcomes for participants. Blair, Giesecke, and Sherman (1991) and Alaimo, Packnett, Miles, and Kruger (2008) each found that community gardeners consume fruits and vegetables at higher rates than nongardeners. McCormack, Laska, Larson, and Story (2010) note the potential for both farmers' markets and community gardens to 
increase access to fruits and vegetables, yet stress that there is limited research assessing the specific health benefits of either type of LFS initiative.

Several LFS studies have noted the lack of assessment tools in this field (Grey, 2000; Hinrichs, Kloppenburg Jr, Stevenson, Lexberg, Hendrickson, and DeMaster, 1998; McCormack, et al., 2010). However, tools developed to assess general food access and the relationship between food access and health outcomes may be useful in assessing the state of LFS initiatives. Presence or absence of different types of food retailers in a particular geographic or demographic area is one indicator of access to food (Alwitt \& Donley, 1997; Bodor, Rose, Farley, Swalm, \& Scott, 2007; Guy \& David, 2004; Lee, Darcy, Leonard, Groos, Stubbs, Lowson, Dunn, Coyne, \& Riley, 2002; Morland, Wing, Diez Roux, \& Poole, 2002). Availability of certain types of foods, often fruits, vegetables, and low-fat dairy, in different types of stores and geographic areas has been used to determine whether local residents have access to healthful foods (Hendrickson, Smith, \& Eikenberry, 2006) and how food access affects health outcomes (Inagami, Cohen, Finch, \& Asch, 2006; Lane, Keefe, Rubinstein, Levandowski, Webster, Cibula, Boahene, Dele-Michael, Carter, Jones, Wojtowycz, \& Brill, 2008; Wang, Kim, Gonzalez, MacLeod, \& Winkleby, 2007), with the general finding that the type of store most available in a given neighborhood affects residents' body mass index. Costs of a selection of foods, usually a predetermined "healthy food basket," have also been compared by geographic or demographic area (Donkin, Dowler, Stevenson, \& Turner, 2000; Guy \& David, 2004; Lee, et al., 2002), demonstrating that food costs and availability often vary within one community depending on the neighborhood. One of the most complete approaches to assessing food access is to determine how far, and by what method, consumers must travel to reach particular types of food by mapping the distance from either individual residence (Algert, Agrawal, \& Lewis, 2006) or neighborhood (Sharkey, Horel, \& Dean, 2010) to a variety of food sources such as supermarkets, small markets, and convenience stores. Some food access studies have included farmers' markets in their assessments, but have focused on markets as a source of fresh produce without considering their status as purveyors of local foods (Bader, Purciel, Yousefzadeh, \& Neckerman, 2010; Larsen \& Gilliland, 2009).

This study applies several of these methods of measuring general food access to the question of access to locally grown foods in order to assess the role local foods currently play in one community's food system. Presence or absence of types of stores, presence or absence of locally grown foods in those stores, price comparisons between locally grown and nonlocal vegetables, and proximity of local and nonlocal food outlets to population centers are all examined in order to assess access to locally grown foods.

These are not new tools, as is clear by the literature cited above. However, they are used in this study for two specific reasons: (1) they have not yet been applied to LFS-specific questions such as equitable access to local food resources, and this study provides an opportunity to test their efficacy in this context; and (2) in our efforts to build our knowledge base about LFS strengths, weaknesses, and best practices, we should use established, successful, and replicable methods capable of producing comparable data both within and across a variety of communities.

If we wish to design food systems that meet community needs through the incorporation of more local production, we must explore the specific outcomes of LFS initiatives on individuals and communities. Fairbanks, as well as many other North American cities, is engaged in the process of building local capacity and it is important, early in the process, to identify existing community needs and the role of nascent LFS initiatives in addressing those needs.

\section{The Fairbanks Food System}

This research took place in Fairbanks, Alaska, primarily during the summers of 2006 and 2007 and describes the community food system as it existed at that time. Assessments such as those conducted in this study must be repeated periodi- 
cally in order to track changes in the community, such as population shifts that might affect the food system and changes in the food system, such as increases or decreases in local production, that might affect the community.

\section{Located at $64^{\circ}$}

north latitude, Fairbanks is the urban hub of Interior Alaska (see figure1). The region is subarctic, with average temperatures that range from $-9.7^{\circ} \mathrm{F}$
Figure 1. The State of Alaska, Fairbanks North Star Borough, and Urban Centers

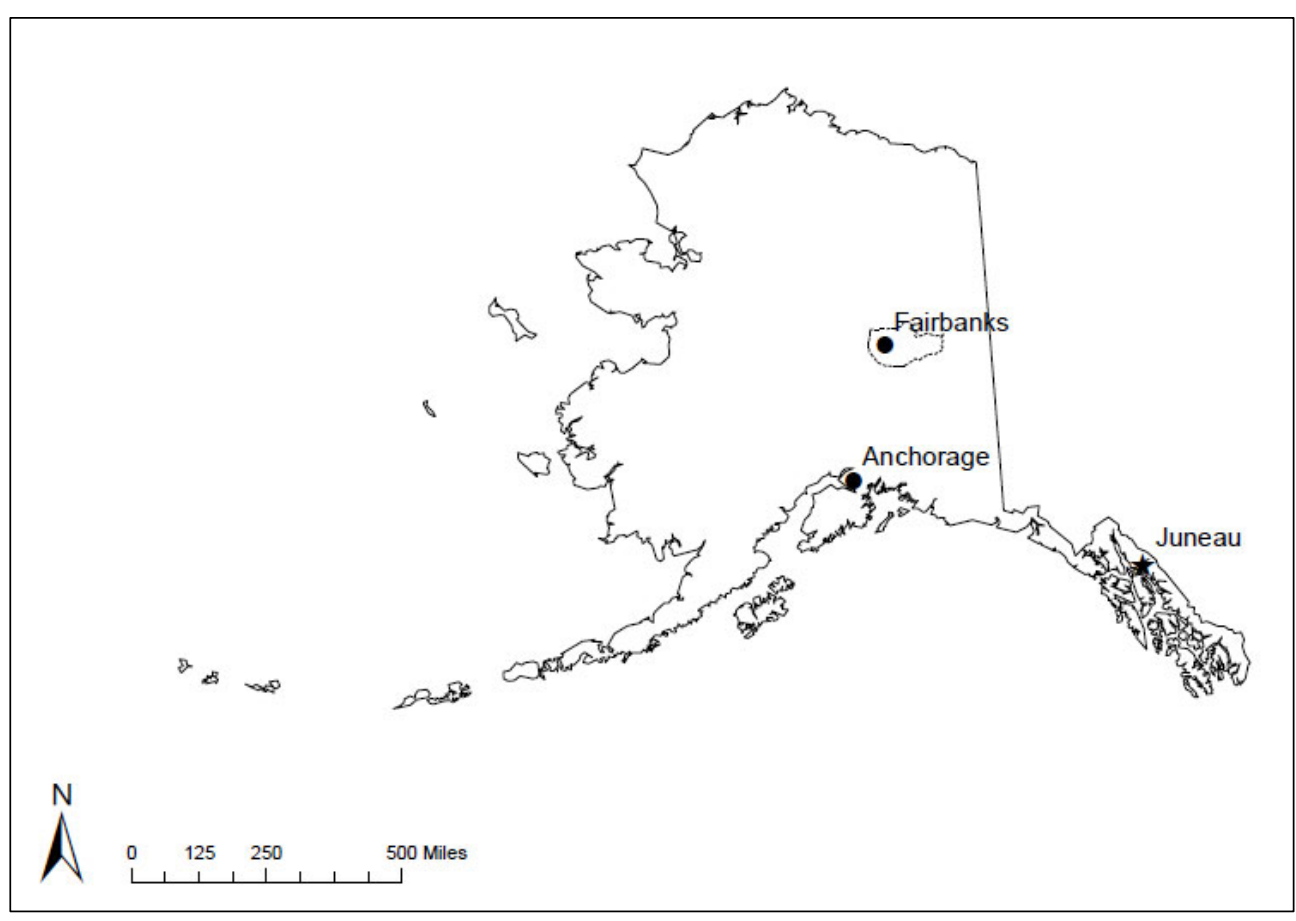

$\left(-23.2^{\circ} \mathrm{C}\right)$ in January

to $+62.4^{\circ} \mathrm{F}\left(16.9^{\circ} \mathrm{C}\right)$ in July. Fairbanks averages 10 days per year below $-40^{\circ} \mathrm{F}\left(-40^{\circ} \mathrm{C}\right)$ and 13 days above $+80^{\circ} \mathrm{F}\left(26.7^{\circ} \mathrm{C}\right)$ (Alaska Climate Research Center, 2008a). There are fewer than 4 hours of daylight at the winter solstice in December and more than 22 hours at the summer solstice in June (Alaska Climate Research Center, 2008b).

Fairbanks receives an average of 10.56 inches $(26.82 \mathrm{~cm})$ of precipitation annually (National Agricultural Statistics Service - Alaska Field Office, 2006). The average growing season for Fairbanks is 115 days (Alaska Climate Research Center, 2008c). In the Fairbanks area, 16,834 acres $(6,812$ hec) of cropland were harvested in 2007; however, only 340 acres $(138 \mathrm{hec})$ of those were vegetables (United States Department of Agriculture, 2009). Agricultural capacity in Fairbanks is somewhat limited due to both climate and soils. There are no Class 1 soils, identified by the USDA as best for agriculture, in Fairbanks. There are approximately 33,000 acres $(13,355$ hec) of Class 2 soils, which have moderate limitations on choice of plants and may require moderate conservation practices, and approximately 6,175 acres $(2,499$ hec) of Class 3 soils, which have more severe limitations on plant choice and higher requirements for conservation practices, in the Greater Fairbanks soil survey area of 264,000 acres (106,837 hec) (United States Department of Agriculture, 2011).

The Fairbanks North Star Borough (FNSB) encompasses the city of Fairbanks, the city of North Pole, and several smaller towns and had a 2007 population of 97,484 people in 7,444 square miles (19,280 square kilometers) (U.S. Census Bureau, 2008b). Because almost all residents rely on a common set of resources for shopping, education, and entertainment located within or near the city limits of Fairbanks, the FNSB is treated as one community; "Fairbanks" is used to refer to the community as a whole.

The food system of Fairbanks reflects its blend of modern U.S. city and historic frontier town. Fairbanks largely relies on the GFS to supply its food. Fairbanks' geographic isolation relative to the contiguous U.S., combined with its subarctic climate, mean that the vast majority of the community's food is imported from great distances outside the state; only an estimated $5 \%$ of food consumed by 
Alaskans is produced in the state of Alaska (University of Alaska Fairbanks Cooperative Extension Service, 2006). The food system includes modern full-service supermarkets; convenience stores; small markets; local farms and a farmers' market; as well as food acquired directly through subsistence hunting or fishing, gathering, or home gardening. The level of participation in subsistence activities makes Fairbanks unique when compared to urban areas outside of Alaska. Due to the manner in which subsistence resources are managed legally within the state, detailed statistics are not kept on urban hunters in Alaska; however, it is estimated that Fairbanks residents, on average, harvest and consume 16 pounds of wild foods per person per year (Wolfe, 2000). Although rural Interior Alaska residents harvest far more subsistence foods annually (up to 613 pounds per person), wild foods remain important parts of the diet and culture of at least some urban residents. While this research focuses on retail-food access, all of these food sources contribute to the food system of Fairbanks and most other Alaskan communities.

The first chain supermarket entered the community in 1961 (Burgett, 1967). In 2007, Fairbanks had nine supermarkets. In addition to five supermarkets representing two national chains, Fairbanks had one "club" store with an annual membership fee and one discount grocer, both owned by a major retail chain, one independent grocer, and one store operated by the U.S. Army, which is not open to the general public.

The community's history and culture, combined with current interests, have kept an LFS component alive for more than 100 years. Gardening and small-scale farming has a rich history in the region (Lewis, 1998; Logsdon, 1983; Papp \& Phillips, 2007). Nevertheless, Fairbanks has struggled with issues of food self-reliance since its founding. Only rarely, for a few years in the 1920s, did the community come close to supplying all its necessary food from local sources (Lewis, 1998; Papp \& Phillips, 2007).
A growing interest in small-scale local food production, combined with this historic interest in self-sufficiency, has helped several small farms, a farmers' market, and a large community garden develop over the past 30 years. The most active local farms, in terms of local food system development, however, are less than 15 years old.

Geographic isolation combined with reliance on national chain supermarkets has implications for Fairbanks' food security in the event of a system shock that disrupts transportation. One of the supermarket chains has a warehouse 350 miles from Fairbanks that supplies the entire state; the other chains have no warehouses in Alaska and must restock all their food directly from the lower 48 states (M. Fern, personal communication, July 9, 2007). Anecdotal estimates, based on discussions with supermarket employees, place the amount of fresh food on hand in the state's supermarkets at two to three days' supply at any given time. A shutdown of the transportation system that brings food into the state by truck, barge, or air could have serious impacts in Fairbanks.

Fairbanks' current food system has several points of vulnerability, both extra-urban and intra-urban, that are common to many North American cities: reliance on foods produced outside the region and shipped into the community (extra-urban vulnerability); diminishing diversity in food suppliers; and migration of supermarkets out of urban core areas and into wealthier suburbs (intra-urban vulnerabilities). Some of Fairbanks' vulnerabilities are unique to high-latitude communities or those in marginal agricultural climates, particularly a short growing season and cold soils that limit local agricultural production.

The similarities between Fairbanks and other U.S. cities allow the use of Fairbanks to test hypotheses about the role of locally grown foods in the current food system. The unique aspects of Fairbanks, namely geographic isolation and challenging climate, make this study imperative for the region as it manages the challenges of rising energy costs, climate change, and population shifts. 


\section{Methods}

\section{Store Type and Availability}

To compare locally grown and imported foods, a sample of seven vegetables was used. Vegetables are the most consistently available locally grown foods that can be easily compared to imported foods. Meat, dairy, and fruits are produced on some farms in the Fairbanks area (United States Department of Agriculture, 2009), but in quantities too small to provide opportunities for consistent price comparisons. The study was conducted in the summer only (June-September), because locally grown vegetables are widely available only during the summer months. This is an admittedly small sample on which to base conclusions about food access. However, the sample is adequate to test the methods of food access assessment within the context of the Fairbanks food system, where the range of locally grown foods is relatively small.

Five vegetables in the sample (broccoli, cabbage, carrots, lettuce, and potatoes) represent the top five vegetables by acres harvested in Alaska (National Agricultural Statistics Service-Alaska Field Office, 2006), which were assumed to be the most readily available vegetables locally. Two vegetables (tomatoes and zucchini) were the two most commonly grown vegetables among community gardeners in Fairbanks and were, therefore, considered to be popular and common vegetables in the area. Information about commonly grown vegetables was gathered during discussions the author held with approximately half of all members ( 29 of 54 people) of the only community garden in
Fairbanks in June 2006.

A list was compiled of food stores in Fairbanks using online search engines and the local phonebook. Fifty-five food outlets were identified and forty-eight were surveyed in person to record the number of fresh items, number, and type of vegetables in other forms (canned, frozen) and the area of origin of each vegetable. Whenever possible during the store surveys, employees or operators (in the case of farm outlets) were interviewed regarding the source of produce, farming methods, and their experiences with sales and marketing of vegetables in Fairbanks.

Seven farm stands listed by the Alaska Department of Health and Social Services (DHSS) as accepting Farmers' Market Nutrition Plan coupons were not directly surveyed because it was not possible to determine whether they were in business at the time of the study. Despite being unable to contact the operators during the study period, the benefit of the doubt was given to the official listings, and the farm stands were included in the physical access assessment. However, they were not included in the price comparisons. Given the short growing season and local climate, all local farm outlets tend to have a similar selection of produce at the same time of year; comparisons of prices at the farmers' market and one farmstand revealed that all farmers charged approximately the same prices for vegetables. Therefore, it was assumed that the unsurveyed farm stands, if open, would stock a similar range of foods at similar prices.

Table 1. Fairbanks Food Outlets Included in Local Food Access Study

\begin{tabular}{lccccc}
\hline Food Outlet & Number & Surveyed & $\begin{array}{c}\text { Fairbanks-grown } \\
\text { available }\end{array}$ & $\begin{array}{c}\text { Alaska-grown } \\
\text { available }\end{array}$ & $\begin{array}{c}\text { Imported } \\
\text { available }\end{array}$ \\
\hline Supermarket & 9 & 9 & 1 (tomatoes only) & 9 & 9 \\
Farmers' market & 1 & 1 & 1 & 0 & 0 \\
CSA $^{a}$ pick-up site & 10 & 10 & 10 & 0 & 0 \\
Single-operator farm stands & 7 & 1 & 7 & 0 & 0 \\
Specialty stores & 4 & 4 & 1 (occasional/limited) & 0 & 4 \\
Convenience stores & 24 & 24 & 0 & 0 & 24 (limited) \\
\hline
\end{tabular}

a CSA = community supported agriculture operation 
Stores were categorized based on the volume and type of vegetables available (see table 1). Although 24 convenience stores and four small or specialty stores are present in Fairbanks, the only consistent sources of a range of fresh vegetables were supermarkets and farm outlets. "Supermarkets" stock a full range of vegetables including all those on the survey list. "Farm outlets" stock mostly or exclusively fresh vegetables that are grown locally (within the Fairbanks area). Farm outlets include the local farmers' market, farm stands, and all pickup sites for CSA enterprises in Fairbanks. For the purposes of this paper, only fresh vegetables are included in the analysis.

Using ArcGIS, stores were geocoded by address and sorted by store type and by availability of Alaska- and/or Fairbanks-grown vegetables. Several addresses could not be geocoded because the road layer available for Fairbanks has incomplete information. Nine stores were digitized individually and then added to the geocoded database. To ensure proper placement of these nine stores, online map services were consulted.

Using 2000 Census data, Fairbanks census tracts were divided into two groups based on median household income: above median household income (higher income) and below median household income (lower income). The nine higherincome tracts combined to account for $57 \%$ of the population and ranged from 3,512 to 8,253 people per tract. Ten lower-income census tracts ranged from 1,128 to 7,381 people per tract and accounted for $43 \%$ of the population. The location of the population centroid for each tract was obtained from the U.S. Census Bureau and plotted onto the map for use during distance analysis. Use of population centroids, a geographical point that identifies the center of an area's population, for large areas such as census tracts is not as accurate as using smaller units such as census blocks; however, census tracts were the smallest scale of socioeconomic data available for Fairbanks.

Although store location can depend on population, household income was used as a variable in order to focus the inquiry on equity issues. Both people and food outlets have migrated toward suburban neighborhoods over the past several decades (Morland \& Wing, 2007), but the market-based argument that retailers simply follow population movements does not address the fact that it is most often lower-income residents left in declining neighborhoods with declining services.

\section{Distance to Food Outlets}

Because presence or absence of a store in a census tract does not guarantee its accessibility to residents, distance to each store was also considered. Distance to food outlets was calculated using the Point Distance tool in ArcGIS to measure from each population-weighted centroid to all stores and to each type of store. Euclidian distance was measured, rather than the usually more accurate Network Distance, because even the most up-to-date GIS maps of the region did not include all roads or addresses, so distance calculations could not be considered entirely accurate using a road-network measure. Euclidian distance likely underestimates the distance between population centroids and destinations because it traces the most direct route, not the route following the existing road network.

Following Sharkey et al. (2010), the mean distance between each population centroid and the 55 food outlets was calculated for each census tract and mean distances to the various store types compared. The U.S. Army Commissary, which is a fullservice supermarket, was excluded from the distance measures for all tracts except number 11, which encompasses the base, because it is not open to the public. However, base residents are free to shop off base so distance to all stores was calculated from the tract 11 population centroid.

\section{Food Costs}

Cost for each type of vegetable included in the sample was gathered during the store survey. The lowest-cost option for each fresh vegetable was recorded at each food outlet. This approach means that, at times, local organic food was compared to conventionally grown imported food, an approach that may have conflated two different issues: cost of locally grown and cost of organically grown. However, from the consumers' perspective these 
two costs are already combined in the price of locally grown food. The consumer's choice is limited to locally grown (which may include costs associated with organic production) and lower-cost conventional foods. Nonetheless, further examination of price differences based on production methods and point of origin would be a fruitful line of inquiry. Costs for vegetables obtained through a CSA subscription are not included due to the difficulty of determining costs for individual vegetables in the CSA system, where food is distributed as a bundle, as well as the limited access to CSAs among the Fairbanks population, where only approximately 350 of 32,352 households were CSA members in 2007 (M. Emers, personal communication, June 3,2007 ).

Cost per ounce for each vegetable is the unit of measurement. Lettuce is the only item not calculated in this manner as all nonpackaged lettuce in the survey was sold per head. The costs of vegetables grown in Fairbanks, in Alaska (but not Fairbanks), and outside Alaska were then calculated for each vegetable. One-way ANOVA was used to compare vegetable costs between the three points of origin.

\section{Results}

Median household income in Fairbanks in 2000 was US\$49,076 and ranged from a high of US\$69,688 in tract 12 to a low of US\$25,901 in tract 1 (U.S. Census Bureau, 2000). Tracts 1-7 encompass the urban core of the community. Lower-income census tracts tend to be clustered in the center of the city with higher income tracts surrounding them (see figure 2). Exceptions are tracts

Figure 2. Fairbanks North Star Borough Census Tracts and 2000 Median Household Income

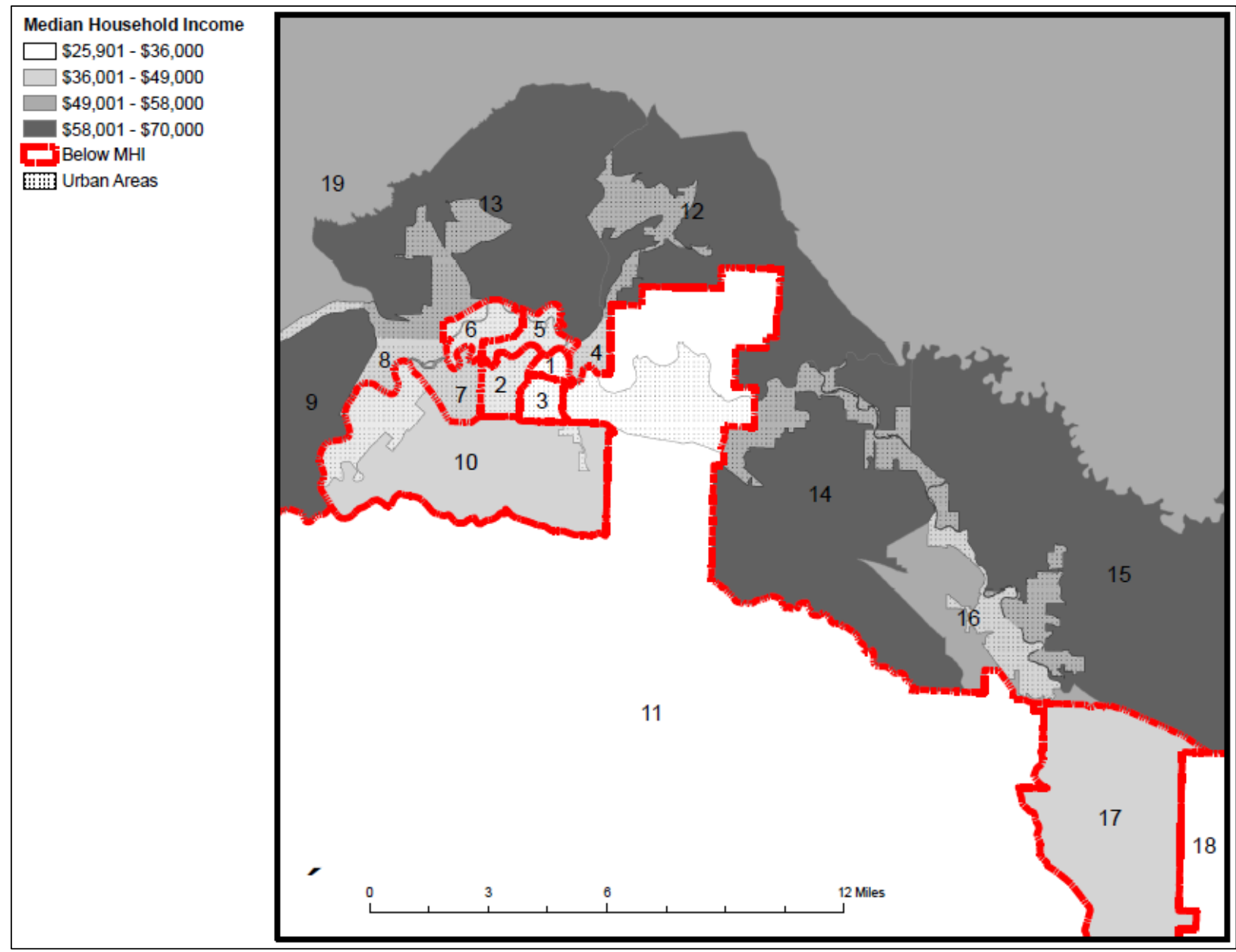




\section{Figure 3. Stores per Census Tract in Fairbanks}

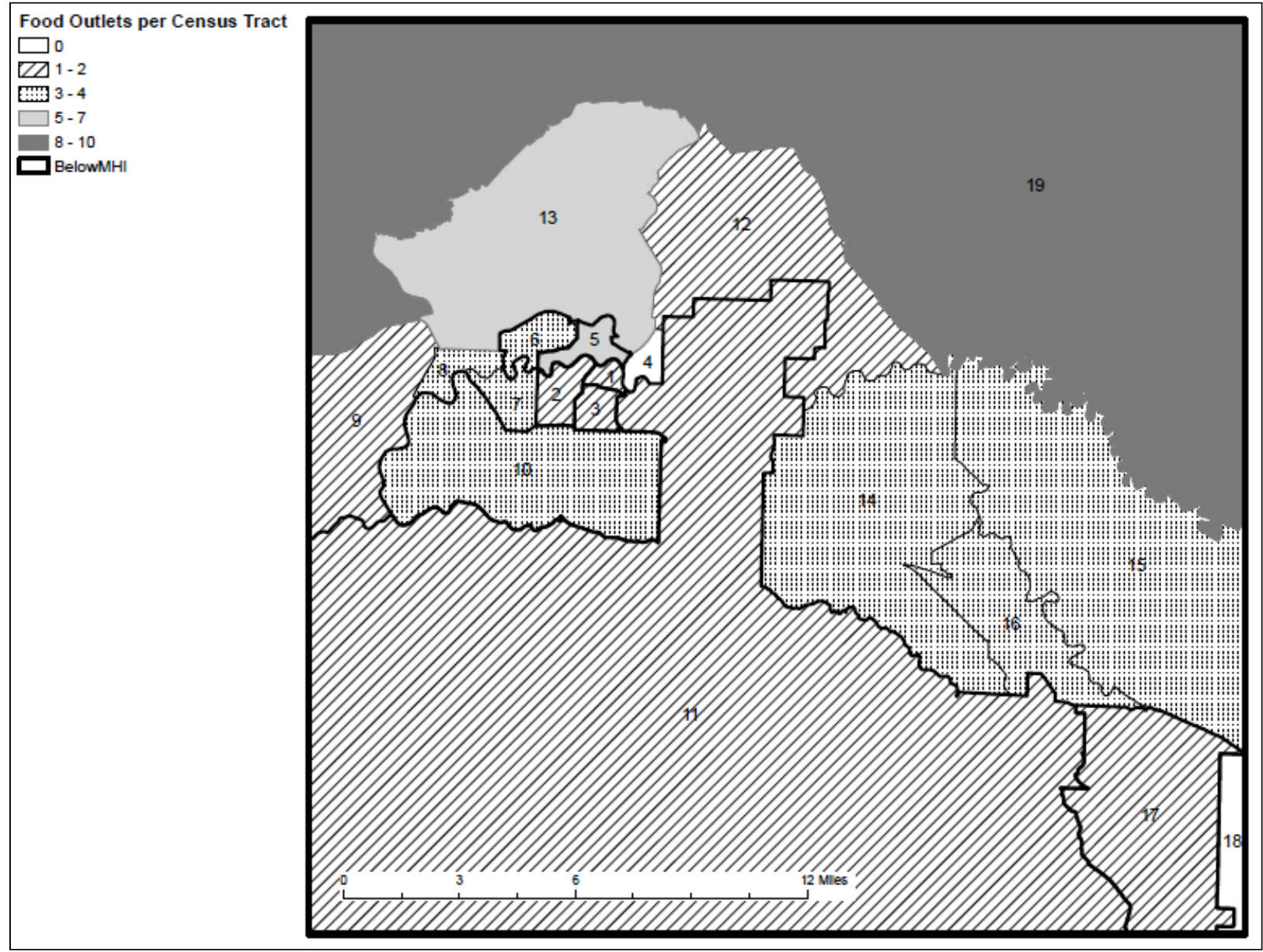

Table 2. Number of Stores and Store Types by Census Tract Type

\begin{tabular}{lccccc}
\hline Tract Type & Total Stores & Convenience & Small & Supermarket & Farm Outlets \\
\hline Lower-Income & 19 & 11 & 3 & 3 & 2 \\
Higher-Income & 36 & 13 & 1 & 6 & 16 \\
\hline Fairbanks & 55 & 24 & 4 & 9 & 18 \\
\hline
\end{tabular}

17 and 18, which are both rural areas to the southeast of the city of Fairbanks.

\section{Allocation of Stores by Census Tract}

The 55 food outlets in Fairbanks were categorized according to availability of fresh produce. Twentyfour of the stores are convenience or conveniencegas stores, which carry five or fewer types of fresh vegetables. Four stores are classified as "small," which stock a limited range (six to 12) of often

each tract type.

\section{Distance to Food Resources}

specialty vegetables. Eighteen farm outlets and nine full-service supermarkets were also identified. Figure 3 illustrates the number of stores in each census tract. Table 2 summarizes the different kinds of stores in

Presence or absence of stores in a particular area neither guarantees nor eliminates access to food resources. An important aspect of access to food is the distance one must travel to reach food resources, and whether or not one has the means to travel that distance. To provide a baseline for understanding food access in Fairbanks, the aver- 
age distance to supermarkets for each tract type was measured. Supermarkets represent the most common location to access a wide range of foods and, therefore, provide us with basic information about food access in the community. By measuring conventional food access, we can then assess whether alternative foods, in this case locally grown foods, are more or less accessible than conventional foods.

Despite a difference of more than 1.5 miles (2.4 $\mathrm{km}$ ), no statistically significant difference was found between the mean distances from lowerincome population centroids to all supermarkets in Fairbanks ( 8.83 miles or $14.21 \mathrm{~km})$ and the mean for higher-income tracts $(7.10$ miles or $11.43 \mathrm{~km})$. See table 3.

The population of Fairbanks, like many western U.S. cities, is dispersed well beyond the city center, making distances to stores high when all stores are considered as a group. The difference in distance to the closest store by census tract provides us with a more realistic picture of food access. For lowerincome tracts, the mean distance to the closest supermarket is 4.47 miles $(7.19 \mathrm{~km})$ and for higherincome tracts is 2.26 miles $(3.64 \mathrm{~km})$, with no statistical significance in the distances. When two rural tracts (17 and 18), in which the closest stores are approximately 20 and 12 miles (32 and $19 \mathrm{~km}$ ) away, respectively, are removed from the lowerincome distance calculations, the average distance to the closest supermarket in lower-income tracts drops to 1.2 miles $(1.93 \mathrm{~km})$, shorter than the aver- age in higher-income tracts. There is still no significant difference between lower-income and higherincome tracts (see table 3).

\section{Local Food Access}

Having established that physical access to conventional foods is, at least statistically, equitable across census tract types, we turn to the question of physical access to locally grown foods. Although some stores in Fairbanks stock locally grown foods occasionally, they rarely had more than one to three items at a time, and these items were not regularly available even during the local growing season. Only one supermarket stocked any Fairbanksgrown foods - and that was only tomatoes grown by one local producer observed during the store surveys. For these reasons, only distance to farm outlets is considered when calculating distance to local foods. The farm outlets are generally open only one or two days each week, but when open provide a range of locally grown vegetables.

The mean distance to outlets for locally grown foods in lower-income tracts is 13.40 miles (21.57 $\mathrm{km})$ and 10.89 miles $(17.53 \mathrm{~km})$ for higher-income tracts - but there is no statistically significant difference between the two. The closest farm outlets range from 0.21 miles $(.34 \mathrm{~km})$ for tract 1 to 17.23 miles $(27.73 \mathrm{~km})$ for tract 17 , with an average distance to the closest of 2.89 miles $(4.65 \mathrm{~km})$. The average closest distance for lower-income tracts is 3.93 miles $(6.32 \mathrm{~km})$ and average closest distance for higher-income tracts is 1.94 miles $(3.12 \mathrm{~km})$. No statistical difference is discernible by tract type.

Table 3. Average Distance to Stores (in Miles and Kilometers) from Census Tract Population Centroids

\begin{tabular}{lccc}
\hline Distance & Lower-Income & Higher-Income & Fairbanks \\
\hline All supermarkets & $8.83 / 14.21$ & $7.10 / 11.43$ & $7.9^{\mathrm{a}} / 12.71$ \\
Closest supermarket & $4.47 / 7.19$ & $2.26 / 3.64$ & $3.31^{\mathrm{b}} / 5.33$ \\
Closest supermarket (excluding tracts 17 \& 18) & $1.20 / 1.93$ & $2.26 / 3.64$ & $\mathrm{~N} / \mathrm{A}$ \\
All local food outlets & $13.40 / 21.57$ & $10.89 / 17.53$ & $12.08^{\mathrm{a}} / 19.44$ \\
Closest local food outlet & $3.93 / 6.32$ & $1.94 / 3.12$ & $2.89 / 4.65$ \\
Farmers' market & & & $7.59^{\mathrm{b}} / 12.21$ \\
\hline
\end{tabular}

a Distance to supermarket compared to distance to local outlet $p=.000$

b Distance to closest supermarket compared to distance to farmers' market $p=.004$ 
Figure 4. Half-mile Walking Distance Buffers Around Census Tract Population Centroids

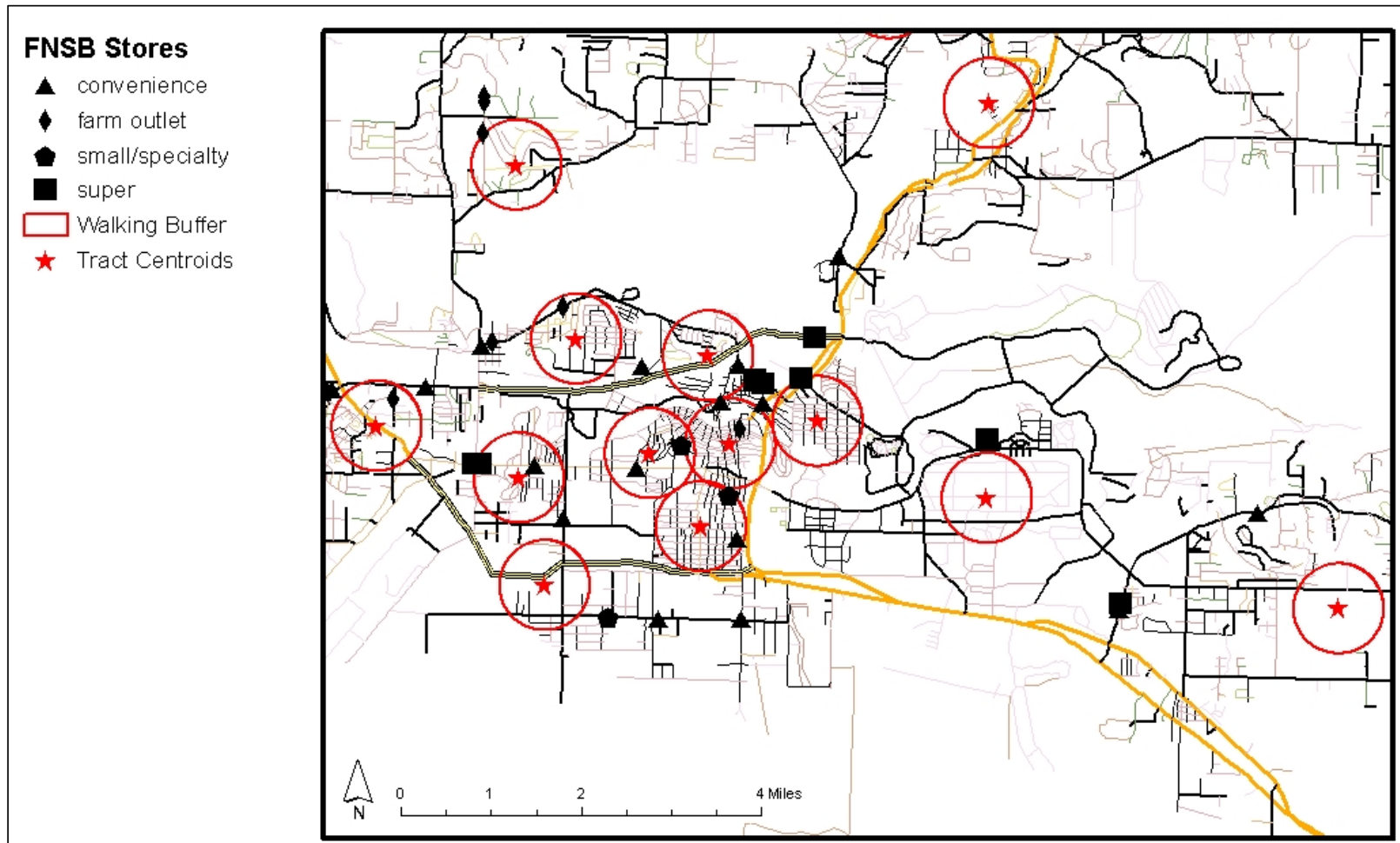

Note. Tracts 17,18, and 19 are not shown as there are no stores within walking distance.

With a farm outlet an average of less than 3 miles $(4.8 \mathrm{~km})$ from each population centroid, it might appear that local foods are actually more accessible than imported. However, this is not necessarily a reasonable assumption. The majority of the farm outlets mapped (10) are CSA pick-up sites, which require consumers to be members in order to access the available food. Only about $1 \%$ of Fairbanks households were served by CSAs in 2007. The vast majority of residents would have needed to purchase locally grown foods at the farmers' market. Given these constraints, it is reasonable to consider the average distance to the farmers' market, 7.59 miles $(12.21 \mathrm{~km})$, as a more accurate estimate of distance to local foods, which is significantly farther than to the closest supermarket $(\mathrm{t}=-3.338, \mathrm{p}=.004)$.

The issue of scheduling and availability — when these outlets are open - is yet another matter that should be considered when assessing the role of locally grown foods in a food system. The farmers' market is open two days per week during the summer months (roughly June through September). The additional distance necessary to reach local food outlets and the limited schedule means that consumers may need to make a separate trip or special arrangements to access local foods. While for many consumers of local foods, these are minor inconveniences in comparison to the perceived benefits of locally grown foods, they can be barriers to increasing the consumer base for local foods to include lower-income people or for those with work, family, or child-care responsibilities that hinder their movement throughout the day (Allen, 1999; Bellows \& Hamm, 2001).

\section{Distance and Transportation}

Although distance to various food outlets appears, on the surface, equitable across census-tract type, these results do not necessarily equate to equitable physical access to food. While distance to a store may be similar for two different households, if access to transportation is not equal across house- 
holds, such distances may mean two entirely different things (Bader et al., 2010). Information on personal transportation ownership by census tract is not available for Fairbanks. However, lowerincome households tend to have lower rates of car ownership (U.S. Census Bureau, 2008a), meaning that travel to shopping must be accomplished by foot, public transportation, or taxi (Algert et al., 2006; Whelan, Wrigley, Warm, \& Cannings, 2002).

To determine whether any stores in Fairbanks are within walking distance of census tract population centers, half-mile buffers were placed around each centroid (see figure 4). One-half mile was chosen as reasonable walking distance based on existing literature ${ }^{1}$ (Algert, et al., 2006). However, the physical structure of a city and its climate must be considered when analyzing walking distance. In many Western U.S. cities, sidewalks are not common, forcing residents to walk in roadways. Additionally, in Fairbanks the impact of climate and geography cannot be ignored. Although this study focuses on summer months, winter conditions in Fairbanks hinder residents' ability to walk to destinations.

Ten of the 19 tract centroids had at least one store within the half-mile buffer. However, only two have a supermarket within walking distance (tracts

Table 4. Vegetable Costs (per ounce), June-July 2007 in the FNSB (all prices in USD)

\begin{tabular}{lccc}
\hline Vegetable & Nonlocal & Alaska-grown & Fairbanks-grown \\
\hline Broccoli & $\$ 0.12$ & $\$ 0.09$ & $\$ 0.19$ \\
Cabbage & $\$ 0.07$ & $\$ 0.05$ & $\$ 0.10$ \\
Carrots & $\$ 0.06$ & $\mathrm{n} / \mathrm{a}$ & $\$ 0.35$ \\
Lettuce & $\$ 1.62$ each & $\$ .99$ each & $\$ 1.94$ each \\
Potatoes & $\$ 0.02$ & $\$ 0.02$ & $\$ 0.10$ \\
Tomatoes & $\$ 0.19$ & $\$ 0.19$ & $\$ 0.26$ \\
Zucchini & $\$ 0.13$ & $\mathrm{n} / \mathrm{a}$ & $\$ 0.11$ \\
\hline
\end{tabular}

${ }^{1}$ U.S. urban planning standards often rely on a $1 / 4$ mile radius for walking distance in dense urban developments. Few neighborhoods in Fairbanks would meet the definition of dense, urban area, so this analysis follows the $1 / 2$ mile distance used in similar studies in communities with similar a similar urban form.
4 and 7), and only one is within walking distance of the farmers' market (tract 6).

Fairbanks has a public transportation system consisting of seven bus routes. Each of the seven lines stops at one of the major grocery stores, and two of the routes stop near the farmers' market. The availability of public transportation can ease food access issues, but does not eliminate them. Doing grocery shopping by bus can be challenging because of the need to walk to and from the closest bus stop, carry grocery bags from the stop, and coordinate shopping trips with bus schedules (Bader et al., 2010; Whelan et al., 2002).

\section{Affordability}

An important dimension of access to food is the affordability of that food. The price analyses here are limited to outlets selling vegetables on a peritem basis (the local farmers' market, one farmstand, and the supermarkets) and excludes CSAs, which, as discussed above, do not itemize their produce and served only a tiny percent of Fairbanks households during this study. However, additional research should be undertaken to assess per-item costs using the CSA approach in order to understand the potential role of CSAs in improving economic access to locally grown foods.

Table 4 summarizes the average price of the seven-vegetable sample by point of origin. Fairbanks-grown vegetables come from farms up to 95 miles (153 $\mathrm{km})$ from the city; Alaska-grown vegetables are from the commercial agricultural area approximately 330 miles $(531 \mathrm{~km})$ from Fairbanks; and nonlocal vegetables come from outside the state and travel as much as 2,400 miles $(3,862 \mathrm{~km})$ to Fairbanks. Alaskagrown vegetables from the MatanuskaSusitna region of Alaska, where food crops are grown on exponentially larger scales than in the interior region of the state, ${ }^{2}$ were available at

\footnotetext{
${ }^{2}$ For example, the Matanuska-Susitna agricultural region produced $128,500 \mathrm{cwt}(5,829$ metric tons) of potatoes and 20,000 cwt $(907 \mathrm{mt}$ ) of carrots in 2005 , compared to the
} 
all supermarkets but one. All prices represent the lowest-cost option for each fresh vegetable at each food outlet at the time of the weekly survey.

Mean prices by region of origin are calculated as cost per ounce, with the exception of lettuce because it was sold per head, not by the pound. There were significant differences between vegetable prices by point of origin $(\mathrm{f}=5.050 ; \mathrm{P}=.009)$. A Bonnferoni post hoc test indicates that Fairbanks-grown vegetables are significantly more expensive than comparable vegetables from each of Alaska-grown and nonlocal sources (see table 5), with Alaska-grown the least expensive option.

Price differences may be affected by seasonal variations in food availability, production methods, and consumer demand. Local potatoes and carrots were not widely available at the time of the survey because they are late-season crops (usually not available until late July at the earliest). Given that both vegetables are relatively inexpensive, they may reduce mean prices for locally grown vegetables. However, the lack of availability of two common vegetables throughout most of the summer in Fairbanks raises issues of access in terms of seasonality and availability of common foods. The short growing season places some limitations on what can be grown locally and how long it will be available throughout the year (Lewis, Hebert, \& Swanson, 2004). Increased reliance on locally grown foods may mean reliance on easily stored produce or food storage practices such as canning and freezing. The potential impacts of climate

\section{Table 5. Price Comparison by Point of Origin}

\begin{tabular}{lcc}
\hline Origin & Average price & Items \\
\hline Nonlocal & $\$ 0.1044 *$ & 48 \\
Alaska-grown & $\$ 0.0708 * *$ & 12 \\
Fairbanks-grown & $\$ 0.1818 *, * *$ & 17 \\
\hline
\end{tabular}

$* p=.026$

$* * p=.015$

Tanana Valley (Fairbanks) region's 37,000 cwt (1,678 mt) and $500 \mathrm{cwt}(23 \mathrm{mt})$ of the same vegetables, respectively. change on agriculture in Fairbanks are discussed in greater detail below.

Farming practices have almost certainly affected the cost of locally grown food. Fairbanks farmers tend to use more sustainable farming methods such as organic or chemical-free production and tend to rely on physical labor rather than mechanized farm equipment, which many farmers advertise at their farm stands and farmers' market stalls. The implications of production techniques are discussed further below.

Finally, demand for locally grown produce is high in Fairbanks. Although only 350 households were served by CSAs in 2007, each CSA farm maintained a waiting list of potential customers. And it was not unusual for farmers selling produce at the farmers' market to completely sell out before the end of the market day (personal observation). With sufficient consumers able and willing to pay higher prices for locally grown foods, there is little incentive for farmers to lower prices, even if that were possible given their expenses and labor inputs.

One attempt to reduce the costs and improve the access of LFS initiatives is the USDA's Farmers' Market Nutrition Plan (FMNP), which provides coupons for use at farmers' markets to low-income families. Similar programs have been successful in improving food access for low-income urban residents elsewhere (Alkon, 2008; Macias, 2008). Participants in the Women, Infants, and Children (WIC) nutrition program and eligible seniors age 60 and older can receive US $\$ 25$ worth of coupons per year through the FMNP to be used at participating local markets or farm stands for Alaskagrown fresh, unprocessed fruits, vegetables, and herbs. The Alaska Department of Health and Social Services estimates that the FMNP generated US $\$ 250,500$ for participating farmers in 2006 (State of Alaska, 2007). DHSS also reports that many participants continued to shop at the local markets after using all of their coupons.

While the FMNP appears to be a successful step toward linking low-income families with local producers, the value of the coupons provided to each 
family is a fraction of average household expenses for fresh vegetables. In 2000, Americans spent an average of US $\$ 1.45$ per person per week for fresh vegetables (Blisard, Stewart, \& Jolliffe, 2004) . A household of four could be expected to spend US $\$ 5.80$ per week on fresh vegetables. The US $\$ 25$ book of coupons per year is equivalent to approximately one month of vegetables per household.

\section{Discussion}

This study captures a snapshot of several components of the Fairbanks food system at one particular moment in time. As with any aspect of a community, we can expect the food system to change over time in response to any number of drivers, including population shifts, climate change, and consumer preference. While some valuable lessons can be gleaned from this preliminary analysis, the real value is in establishing food access indices (Pearce, Witten, \& Bartie, 2006) that can, and should, be revisited over time. For example, since the data was collected for this study, the single farmstand in downtown Fairbanks has evolved into a multivendor weekly farmers' market. While not likely to significantly change the physical or economic access equity issues on its own, the additional market does provide more choices for consumers and greater exposure to locally grown foods for community members.

Other baseline indicators identified through this study should be revisited in the near future to assess community progress toward greater access to locally grown foods and greater equity in the food system in general. The current pattern of geographic allocation of food outlets across Fairbanks revealed few differences between lower- and higher-income census tracts in terms of their physical distance to food. In fact, some lowerincome census tracts are closer (1.2 miles or $1.9 \mathrm{~km}$ on average) to supermarkets than higher-income tracts (2.26 miles or $3.64 \mathrm{~km}$ on average). However, statistical differences are not the same as discernible differences for the people who confront their food-access issues regularly. Lack of access to personal transportation may make the 1.2 miles to the closest supermarket in lower-income tracts a bar- rier for some households. And with few stores within walking distance of population centers, many residents may find their physical access to healthful foods somewhat limited. Additional research that determines how people travel to food outlets would be beneficial to the community in terms of planning for future food outlets or alternative food access programs.

This study found that locally grown foods are less physically accessible than conventional foods on a communitywide scale. Locally grown foods are not available in supermarkets. The most consistent source of local food, at the time of writing, was one farmers' market, which is significantly farther away from population centers (7.59 miles or 12.21 $\mathrm{km}$ ), on average, than are the closest supermarkets (3.31 miles or $5.33 \mathrm{~km}$ ). CSA pick-up sites provide one successful model for physical food access because they are intended to be convenient to farm shareholders. Inclusions of CSA pick-up sites in the spatial analysis of food access points helped to drop the average distance to local food resources to 2.89 miles $(4.65 \mathrm{~km})$ on average. However, in the case of Fairbanks, these enterprises were limited in terms of their ability to meet current demand, serving only about $1 \%$ of community households, and therefore were not currently contributing to local food access at a communitywide scale. Revisiting both the effect on local food access of the new farmers' market and the percent of Fairbanks households engaged with CSAs is an important task for LFS practitioners and planners.

Locally grown vegetables in Fairbanks were more expensive than the lowest-cost comparable vegetables available in supermarkets. Affordability of food is affected by production methods, location of production, and consumers' ability to pay (Ericksen, 2008). Practicing more ecologically sensitive production methods, as many Fairbanks farmers do, may improve environmental and human-health outcomes, but it can be financially difficult because farmers may lose out on the benefits of economies of scale and government subsidies (Fraser, Mabee, \& Figge, 2005) and the practices tend to be more labor intensive, further raising farmer costs. Switching to more conven- 
tional farming methods may lower food prices, but poses potential harm to the local environment and may reduce the interest of some consumers who value environmentally sensitive growing techniques. If sustainable agriculture costs fall over time, as Horrigan, Lawrence, and Walker (2002) suggest, Fairbanks might see prices for locally grown foods fall as farms become better established. Including age of farm as a variable in future price analysis may elucidate this effect.

The location of food production can affect food costs in two ways: cost of transportation and availability of local resources. In Fairbanks, locally grown foods travelled no more than 95 miles (153 $\mathrm{km})$ to the farmers' market, compared to more than 2,400 miles $(3,862 \mathrm{~km})$ for some imported vegetables, yet were more expensive. Transportation costs are, therefore, less of a driver of local food costs than factors like production methods (discussed above) and local agricultural capacity. Soils in the Fairbanks area are not ideal for agriculture (USDA Class 2 and 3 only). Poor soils place some limits on yield as well as crop choice. In addition, the short growing season means farmers have a limited window in which to recoup their costs through sales. Climate change in the region is expected to extend the growing season (Juday et al., 2005). However, other expected changes like increased drying will likely limit future agricultural potential (ibid). The Arctic Climate Impact Assessment found that the additional costs for irrigation, which will be necessary given a drier climate, may increase the costs of farming in the region and, therefore, keep the price of foods grown in arctic regions higher than those grown in more conventional agricultural regions (Juday et al., 2005).

Variables to consider in future research should include farming methods, length of production season on each farm, and yield per acre on each farm. In the case of this study, further separating locally grown foods by farming methods (organic, chemical-free, or conventional) may have resulted in samples too small to accurately compare, but this approach should be applied in future studies whenever possible.
High demand for locally grown foods, evidenced by waiting lists for CSA memberships and brisk sales at the farmers' market, also affects food prices. Clearly, some consumers are able and willing to pay higher prices because they value food produced locally. If farmers can charge higher prices, and recoup more of their costs, they have little incentive to lower prices simply to improve food access.

In the short term, government-funded programs like the Farmers' Market Nutrition Program indirectly subsidize small farmers by helping lowincome households participate in LFSs. However, the program depends in the government's ability and willingness to subsidize the food system and has, so far in Alaska, provided a relatively small subsidy of US $\$ 25$ per year - roughly equivalent to one month's worth of vegetables for a family of four.

The finding that commercially grown vegetables from south-central Alaska are less expensive than either locally grown or imported vegetables and are at least as physically accessible (seasonally) as imported foods is illustrative of a principal perhaps not discussed enough in alternative food systems research: the need to move beyond the false dichotomy of global and local (Hinrichs et al., 1998). It is not within the scope of this paper to determine whether these regionally, but not immediately local, foods could fill food system gaps in Fairbanks. But, this finding prompts us to look beyond philosophical arguments to search for those food system practices that most effectively meet the needs of the most people now and into the future. Future research should explore the potential for both regions - Fairbanks and southcentral Alaska - to expand production to meet the food and nutritional security needs of state residents.

Accurate assessment of food system indices requires the use of the best data available. Several data weaknesses should be remedied in future work in this geographic and subject area. In the case of this study, the smallest census unit for which socioeconomic data was available was the census tract. 
Census blocks would be a far more effective unit of study and should be used, whenever possible, in similar research elsewhere. Network distance, which measures distance along existing transportation pathways, is a preferred measure when assessing distance to a resource. Outdated GIS maps for the Fairbanks area made Euclidean distance preferable in this particular case. However, future studies, particularly those focused on methods of transportation to food outlets, would benefit from use of network distance measurements.

\section{Conclusions}

Assessment of local food system initiatives, such as this study, are only one step in the process of redesigning and redeveloping our food systems to ensure provision of food security, environmental security, and social welfare. Once access indices have been identified for a community, assessments should be repeated periodically to track changes in the food system.

This snapshot of the Fairbanks food system, and local components within the system, has revealed some important patterns. Physical access to healthful foods (represented by access to supermarkets) is fairly equitable across economic levels — with the caveat that, without personal transportation, some households may struggle more than others to access supermarkets. However, all residents, regardless of income, are likely to have somewhat less access to locally grown foods. New local food outlets, such as the recently expanded market in downtown Fairbanks, may improve access and exposure to local produce over time. And, because existing CSAs provide a good model of physical access, any increases in CSA capacity may also contribute to improved physical access over time.

Improving economic access to locally grown foods presents more of a challenge. At present, locally grown vegetables are significantly more expensive than the lowest-cost comparable alternatives in supermarkets. Further research should be focused on determining those factors, such as farming methods, size and age of farm, and consumer demand, that most affect the price of locally grown foods and whether opportunities exist to make changes in these variables and thus to improve economic access.

A key finding from this assessment is that regionally, but not immediately local, vegetables were the least expensive choice found in the store surveys and were widely available in supermarkets. It may help to close local food access gaps in Fairbanks if the definition of "local" is broadened to include regionally produced foods. Regionally grown vegetables meet several of the goals of LFS development, particularly reduction of food miles and support for local economies. However, these regionally grown vegetables are not necessarily grown using organic methods, as many locally grown food are. Although they provide a middle ground, reliance on this source of food leaves the community at risk of sustaining a two-tiered food system (Friedmann, 2010) in which some residents can participate in a local system that provides organic, fresh foods, while some residents are limited to a different set of foods: less local, nonlocal, non-organic, or a combination thereof.

The relative accessibility of regionally grown vegetables, as well as concerns about the potential for sustained inequity in the food system, illustrate why it is important to assess individual food systems. We must be able to identify those components of the food system that are most successful based on a number of metrics, including accessibility, environmental impacts, and cultural acceptability, and track changes in how those components function over time.

The process of improving our food systems will take experimentation, adaptation, and, likely, compromise. The focus in food system planning should be on developing a set of best practices that can be demonstrated to meet the food security needs of the most people now and into the future. Spatial analysis and other quantitative assessments, such as those used in this study, that reveal patterns in both conventional and alternative food system components can be used to help LFS practitioners and planners identify gaps and opportunities in their communities. 
Practices and approaches that improve the key food system outcomes of food security, environmental security, and social welfare should drive food system design. More research is needed in this area in order to address significant data gaps in the overall effectiveness of alternative food system initiatives in meeting these key outcomes, particularly in the area of equitable food access. More rigorous assessments of all sectors of food systems should be undertaken to begin the process of collecting a set of best practices that can be shared among and adapted to all communities.

\section{Acknowledgements}

The author wishes to thank Dr. S. Craig Gerlach, University of Alaska Fairbanks Center for Cross Cultural Studies; Dr. Phyllis Morrow and Dr. Joel D. Irish, University of Alaska Fairbanks Department of Anthropology; Dr. Jonathan Rosenberg, University of Alaska Fairbanks Department of Political Science; and Dr. Scott Rupp, University of Alaska Fairbanks School of Natural Resources and Agricultural Science for their invaluable input, support, and guidance on this research. Several anonymous reviewers as well as the editor provided excellent insights and suggested improvements to earlier drafts of this work.

\section{References}

Alaimo, K., Packnett, E., Miles, R. A., \& Kruger, D. J. (2008). Fruit and vegetable intake among urban community gardeners. Journal of Nutrition Education and Behavior, 40(2), 94-101. http://dx.doi.org/10.1016/j.jneb.2006.12.003

Alaska Climate Research Center. (2008a). Alaska climate data - temperature. Retrieved July 18, 2008, from http://climate.gi.alaska.edu/Climate/Temperature/ index.html

Alaska Climate Research Center. (2008b). Alaska sunrise-sunset. Retrieved July 18, 2008, from http://climate.gi.alaska.edu/Climate/Sunrise set/ index.html

Alaska Climate Research Center. (2008c). Frost/freeze dates of occurrence and length of growing season. Retrieved November 14, 2008, from http://climate.gi.alaska.edu/Climate/Atlas/tables/ Temperature/ff8.html
Algert, S. J., Agrawal, A., \& Lewis, D. S. (2006). Disparities in access to fresh produce in lowincome neighborhoods in Los Angeles. American Journal of Preventive Medicine, 30(5), 365-370. http://dx.doi.org/10.1016/j.amepre.2006.01.009

Alkon, A. H. (2008). From value to values: Sustainable consumption at farmers markets. Agriculture and Human Values, 25, 487-498. http://dx.doi.org/10.1007/s10460-008-9136-y

Allen, P. (1999). Reweaving the food security safety net: Mediating entitlement and entrepreneurship. Agriculture and Human V alues, 16, 117-129. http://dx.doi.org/10.1023/A:1007593210496

Alwitt, L. F., \& Donley, T. D. (1997). Retail stores in poor urban neighborhoods. Journal of Consumer Affairs, 31(1), 139-163. http://dx.doi.org/ 10.1111/j.1745-6606.1997.tb00830.x

Bader, M. D. M., Purciel, M., Yousefzadeh, P., \& Neckerman, K. M. (2010). Disparities in neighborhood food environments: Implications of measurement strategies. Economic Geography, 86(4), 409-430. http://dx.doi.org/10.1111/j.1944$\underline{8287.2010 .01084 . x}$

Bellows, A. C., \& Hamm, M. W. (2001). Local autonomy and sustainable development: Testing import substitution in localizing food systems. Agriculture and Human V alues, 18, 271-284. http://dx.doi.org/10.1023/A:1011967021585

Blair, D., Giesecke, C. C., \& Sherman, S. (1991). A dietary, social and economic evaluation of the Philadelphia Urban Gardening Project. Journal of Nutrition Education, 23, 161-167.

Blisard, N., Stewart, H., \& Jolliffe, D. (2004). Low-income households' expenditures on fruits and vegetables (No. ARS \#833). Washington, D.C.: United States Department of Agriculture.

Bodor, J. N., Rose, D., Farley, T., Swalm, C., \& Scott, S. K. (2007). Neighborhood fruit and vegetable availability and consumption: The role of small food stores in an urban environment. Public Health Nutrition, 11(4), 413-420.

Burgett, G. J. (1967). An analysis of food retailing in the Fairbanks-North Star Borough with particular emphasis upon pricing and promotion during the period 1960-1966 (Unpublished master's thesis). University of Alaska Fairbanks: Fairbanks, Alaska. 
Donkin, A. J., Dowler, E. A., Stevenson, S. J., \& Turner, S. A. (2000). Mapping access to food in a deprived area: The development of price and availability indices. Public Health Nutrition, 31(1), 31-38.

Ericksen, P. J. (2008). Conceptualizing food systems for global environmental change research. Global Environmental Change, 18, 234-245.

Feenstra, G. (2002). Creating space for sustainable food systems: Lessons from the field. Agriculture and Human Values, 19, 99-106. http://dx.doi.org/10.1023/A:1016095421310

Fraser, E. D. G., Mabee, W., \& Figge, F. (2005). A framework for assessing the vulnerability of food systems to future shocks. Futures, 37, 465-479. http://dx.doi.org/10.1016/j.futures.2004.10.011

Friedmann, H. (2010). Plan B - A different food system is possible. The FOOD Magazine.

Grey, M. A. (2000). The industrial food stream and its alternatives in the United States: An introduction. Human Organization, 59(2), 143-150.

Guthman, J. (2008). "If they only knew": Color blindness and universalism in California alternative food institutions. The Professional Geographer, 60(3), 387-397. http://dx.doi.org/10.1080/00330120802013679

Guthman, J., Morris, A. W., \& Allen, P. (2006, December). Squaring farm security and food security in two types of alternative food institutions. Rural Sociology, 71(4), 662-684.

Guy, C. M., \& David, G. (2004). Measuring physical access to "healthy foods" in areas of social deprivation: A case study in Cardiff. International Journal of Consumer Studies, 28(3), 222-234. http://dx.doi.org/10.1111/j.14706431.2003.00340.x

Hendrickson, D., Smith, C., \& Eikenberry, N. (2006). Fruit and vegetable access in four low-income food deserts communities in Minnesota. Agriculture and Human V alues, 23, 371-383. http://dx.doi.org/10.1007/s10460-006-9002-8

Hendrickson, M. K., \& Heffernan, W. D. (2002). Opening spaces through relocalization: Locating potential resistance in the weaknesses of the global food system. Sociologia Ruralis, 42(4), 347-369. http://dx.doi.org/10.1111/1467-9523.00221

Hinrichs, C. C. (2003). The practice and politics of food system localization. Journal of Rural Studies, 19(1), 33-45.
Hinrichs, C. C., Kloppenburg Jr., J., Stevenson, S., Lezberg, S., Hendrickson, J., \& DeMaster, K. (1998). Moving beyond "global" and "local": NE-185 working statement. United States Department of Agriculture.

Hinrichs, C. C., \& Kremer, K. S. (2002). Social inclusion in a Midwest local food system project. Journal of Poverty, 6(1), 65-90. http://dx.doi.org/10.1300/J134v06n01_04

Horrigan, L., Lawrence, R. S., \& Walker, P. (2002). How sustainable agriculture can address the environmental and human health harms of industrial agriculture. Environmental Health Perspectives, 110(5), 445-456. http://dx.doi.org/10.1289/ehp.02110445

Inagami, S., Cohen, D. A., Finch, B. K., \& Asch, S. M. (2006). You are where you shop: Grocery store locations, weight, and neighborhoods. American Journal of Preventive Medicine, 31(1), 10-17. http://dx.doi.org/10.1016/j.amepre.2006.03.019

Juday, G. P., Barber, V., Duffy, P., Linderholm, H., Rupp, T. S., Sparrow, S., et al. (2005). Forest, land management, and agriculture. In Arctic Climate Impact Assessment. Arctic Climate Impact Assessment (pp.781-862). Cambridge, U.K: Cambridge University Press. Retrieved from http://www.acia.uaf.edu/

Kloppenburg Jr., J., Hendrickson, J., \& Stevenson, G. W. (1996). Coming into the foodshed. Agriculture and Human Values, 13(3).

Lane, S. D., Keefe, R. H., Rubinstein, R. A., Levandowski, B., Webster, N., Cibula, D. A., et al. (2008). Structural violence, urban retail markets, and low birth weight. Health and Place, 14, 415-423. http://dx.doi.org/10.1016/j.healthplace.2007.08. $\underline{008}$

Larsen, K., \& Gilliland, J. (2009). A farmers' market in a food desert: Evaluating impacts on the price and availability of healthy food. Health \& Place, 15(4), 1158-1162. http://dx.doi.org/10.1016/ j.healthplace.2009.06.007

Lee, A. J., Darcy, A. M., Leonard, D., Groos, A. D., Stubbs, C. O., Lowson, S. K., et al. (2002). Food availability, cost disparity and improvement in relation to accessibility and remoteness in Queensland. Australian and New Zealand Journal of Public Health, 26(3), 266-272. http://dx.doi.org/ 10.1111/j.1467-842X.2002.tb00685.x 
Lewis, C. E. (1998). Alaska's agriculture: Examining 100 years of growth, lean times. Agroborealis, 30(1), 38-44.

Lewis, C. E., Hebert, M., \& Swanson, R. (2004). Ask for Alaska Grown. Fairbanks, Alaska: University of Alaska Fairbanks Cooperative Extension Service.

Logsdon, C. E. (1983). A brief history of Alaska's agriculture. In H. L. NcNicholas (Ed.), Alaska's Agriculture and Forestry. Fairbanks, Alaska: University of Alaska Fairbanks Cooperative Extension Service.

Macias, T. (2008). Working toward a just, equitable, and local food system: The social impact of communitybased agriculture. Social Science Quarterly, 89(5), 1086-1101. http://dx.doi.org/10.1111/j.15406237.2008.00566.x

McCormack, L. A., Laska, M. N., Larson, N. I., \& Story, M. (2010). Review of the nutritional implications of farmers' markets and community gardens: A call for evaluation and research efforts. Journal of the American Dietetic Association, 110(3), 399-408. http://dx.doi.org/10.1016/j.jada.2009.11.023

Morland, K., \& Wing, S. (2007). Food justice and health in communities of color. In R. D. Bullard (Ed.), Growing Smarter: Achieving Livable Communities, Environmental Justice, and Regional Equity (pp. 171188). Cambridge, Massachusetts: The MIT Press. Morland, K., Wing, S., Diez Roux, A., \& Poole, C. (2002). Neighborhood characteristics associated with the location of food stores and food service places. American Journal of Preventive Medicine, 22(1), 23-29. http://dx.doi.org/10.1016/S07493797(01)00403-2

National Agricultural Statistics Service - Alaska Field Office. (2006). Alaska agricultural statistics. Palmer, Alaska: U.S. Department of Agriculture.

Papp, J. E., \& Phillips, J. A. (2007). Like a tree to the soil: A bistory of farming in Alaskea's Tanana Valley, 1903 to 1940. Fairbanks, Alaska: University of Alaska Fairbanks Alaska Agricultural and Forestry Experiment Station.

Pearce, J., Witten, K., \& Bartie, P. (2006). Neighbourhoods and health: A GIS approach to measuring community resource accessibility. Journal of Epidemiology and Community Health, 60, 389-395. http://dx.doi.org/10.1136/jech.2005.043281

Pirog, R., \& Benjamin, A. (2003). Checking the food odometer: Comparing food miles for local versus conventional produce sales to Iowa institutions. Ames, Iowa: Leopold Center for Sustainable Agriculture.

Sen, A. (1981). Poverty and famines: An essay on entitlement and deprivation. Oxford, U.K.: Clarendon Press.

Sharkey, J. R., Horel, S., \& Dean, W. R. (2010). Neighborhood deprivation, vehicle ownership, and potential spatial access to a variety of fruits and vegetables in a large rural area in Texas. International Journal of Health Geographics, 9, 27. http://dx.doi.org/10.1186/1476-072X-9-26

State of Alaska. (2007). Alaska Farmers' Market Nutrition Program. http://hss.state.ak.us/dpa/programs/ nutri/FMNP/Default.htm

Sundkvist, A., Milestad, R., \& Jansson, A. (2005). On the important of tightening feedback loops for sustainable development of food systems. Food Policy, 30, 224-239. http://dx.doi.org/10.1016/ j.foodpol.2005.02.003

U.S. Census Bureau. (2000). Fairbanks North Star Borough Census 2000 Summary: File 3, Matrices P53, P77, P82, P87, P90, PCT47, and PCT52. Washington, D.C.: Census Bureau.

U.S. Census Bureau. (2008a). Asset ownership rates for households, by selected characteristics: 2002. Washington, D.C.: Census Bureau.

U.S. Census Bureau. (2008b). Population Finder: Fairbanks North Star Borough, Alaska. http:/ quickfacts.census. gov/qfd/states/02/020901k.html

United States Department of Agriculture. (2009). 2007 Census of Agriculture: Alaska state and area data. Washington, D.C.

United States Department of Agriculture. (2011). Web soil survey. http://websoilsurvey.nrcs.usda.gov/ app/HomePage.htm

University of Alaska Fairbanks Cooperative Extension Service. (2006). The agricultural industry in Alaska: $A$ changing and growing industry — Identification of issues and challenges. Fairbanks, Alaska: University of Alaska Fairbanks.

Wang, M. C., Kim, S., Gonzalez, A. A., MacLeod, K. E., \& Winkleby, M. A. (2007). Socioeconomic and food-related physical characteristics of the neighborhood environment are associated with body mass index. Journal of Epidemiology and Community Health, 61, 491-498. http://dx.doi.org/10.1136/jech.2006.051680 
Whelan, A., Wrigley, N., Warm, D., \& Cannings, E. (2002). Life in a "food desert." Urban Studies, 39(11), 2083-2100. http://dx.doi.org/ $\underline{10.1080 / 0042098022000011371}$
Wolfe, R. J. (2000). Subsistence in Alaska: A year 2000 update. Juneau, Alaska: Alaska Department of Fish and Game. 